\title{
Ayurvedic Management of Deep Vein Thrombosis with Stroke and Hypothyroidism - A Case Report
}

\begin{abstract}
Deep vein thrombosis (DVT) is the third most common vascular disease, after ischemic heart disease (IHD) and stroke and it is a silent killer. It affects approximately $0.1 \%$ of persons per year. Various treatment modalities and drugs of western medicine such as surgical interventions, urokinase, streptokinase or tissue plasminogen activators to dissolve the blood clots have their own limitations and side effects apart from being expensive. The present report deals with a case of DVT with 'Stroke' \& 'Hypothyroidism' diagnosed as 'Ekanga shotha' / 'Raktavrita vata' \& 'Pakshaghata' according to Ayurveda. Various Ayurvedic panchakarma procedures and internal medicines have provided promising results especially in reducing the swelling (of left lower limb caused by DVT), decreasing the severity of thrombosis (from complete thrombosis to partial in proximal superficial femoral vein and common femoral vein) in deep veins, managing various associated conditions like hypothyroidism, hypercholesterolemia, hypertension, stroke in a better way and also improving quality of life without causing any adverse effects in present case within two months of Ayurvedic treatment. Ayurvedic treatment seems to be promising in the management of DVT with stroke and hypothyroidism.
\end{abstract}

Keywords: Deep vein thrombosis; DVT; Hypothyroidism; Stroke; Panchakarma, Ayurveda

\begin{abstract}
Case Report
Volume 9 Issue 2 - 2017

Prasad Mamidi* and Kshama Gupta

Department of Kayachikitsa, Parul University, India

*Corresponding author: Prasad Mamidi, Associate

Professor, Dept of Kayachikitsa, Faculty of Ayurveda, Parul

University, Vadodara, Gujarat, India, Tel: 7567222856; Email:

drprasadmamidi@gmail.com
\end{abstract}

Received: February 26, 2017 | Published: October 20, 2017

\section{Introduction}

Deep vein thrombosis (DVT) is the third most common vascular disease, after ischemic heart disease (IHD) and stroke and it is a silent killer. The mechanism underlying DVT, known as Virchow's triad, are venous stasis, hypercoagubility and endothelial injury. DVT may cause life threatening condition like pulmonary embolism due to dislodgement of thrombus [1]. DVT has an estimated annual incidence of 67 per 100000 among the general population [2]. DVT commonly affects the leg veins like femoral vein, popliteal vein and the deep veins of the pelvis. Immobility, hypercoagubility and trauma to the vein are the common causes for development of DVT [3]. Increasing age and stroke/paralysis etc clinical conditions predispose to venous thrombo embolism (VTE) in adults [4]. Patients may complain of pain in the calf muscles and thighs and may present with swollen legs. There may be tenderness, palpable thick vein, distended veins, discoloration or cyanosis [5].

Treatment of DVT aimed at reduction the propagation of thrombus, to limit the damage to the venous valves and to prevent pulmonary embolism. Management of DVT by western medicine consists of, bed rest, elevation of legs, elastic stockings, use of drugs like heparin, coumarine derivatives (warfarins), fibrinolytic drugs (streptokinase) and aspirin etc [1]; Various treatment modalities and drugs such as surgical interventions, urokinase, streptokinase or tissue plasminogen activators to dissolve the blood clots have their own limitations and side effects apart from being expensive [6]. DVT can be correlated with various conditions like, 'Raktavrita vata', 'Siragata vata', 'Vatarakta' etc., mentioned in Ayurveda and procedures like, 'Rakta mokshana' (bloodletting)/'Jalookavacharna' (leech application) have been proved beneficial in the management of DVT $[1,3]$.
The present report deals with a case of DVT with 'Stroke' \& 'Hypothyroidism' diagnosed as 'Ekanga shotha' [7] / 'Raktavrita vata' [8] \& 'Pakshaghata' [9] according to Ayurveda. Written informed consent was obtained from the patient for the publication of the present case report.

\section{Case Description}

A 52 year old female patient came to our care (10.10.2016) with the complaints of left side hemiparesis and swelling of left lower limb (Figure 1). Patient was diagnosed as having 'DVT' along with 'Ischemic cardio vascular stroke', 'Hypothyroidism' \& 'Hypertension' and has been receiving treatment for the same since six weeks (24.08.2016). Patient has been taking anti hypertensives, aspirin, warfarins, thyroid supplements, fibrinolytic drugs, multi vitamins and laxatives. Patient didn't get satisfactory and sustained relief with these medicines. Patient has decided to get Ayurvedic treatment and came to our care. The patient was able to walk with support, fully conscious / alert and the swelling of left lower limb was not associated with pain.

Reduced hemoglobin levels $(10.2 \mathrm{gm} / \mathrm{dl})$, increased prothrombin time (36.2 seconds), disturbed lipid profile and elevated TSH (Thyroid Stimulating Hormone) levels (46.66u $\mathrm{IU} / \mathrm{ml}$ ) were found before / initial stages of an Ayurvedic treatment (05.10.2016, 07.10.2016 \& 20.10.2016). Lower limb venous Doppler showed, 'Common femoral vein (CFV) and Superficial femoral vein (SFV) shows echogenic content with no probe compressibility; Anterior tibial vein (ATV), Posterior tibial vein (PTV), Peroneal vein (PV) show normal flow and probe compressibility; DVT involving CFV, SFV \& Popliteal vein (27.09.2016). X-Ray of chest (AP view) has showed, consolidation of mid zone of left lung (19.09.2016) (Table 1). 


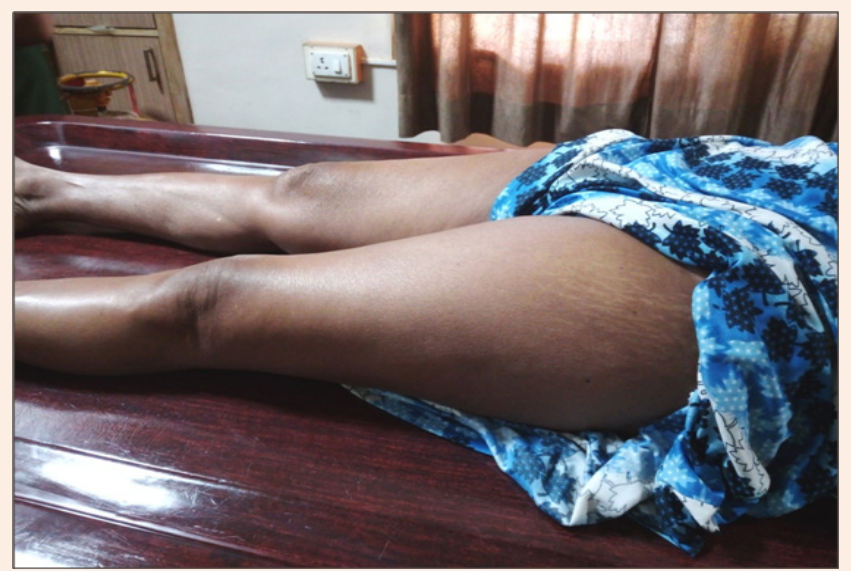

Figure 1: DVT - Left lower limb (before treatment).

No past history of head injury, diabetes, and any major medical illness found except hypertension and hypothyroidism. Negative family history of stroke, diabetes, hypertension, dyslipidemia and cardio-vascular pathology found. At the time of examination patient's vital functions were normal and patient was conscious, oriented, responding to vocal commands with no speech

Table 1: Investigation reports. disturbances and no facial involvement. Patient was able to walk with support. Tendon reflexes were exaggerated, muscle tone was increased and power was +2 in right upper and lower limb with positive babinski. Swelling of left lower limb was found with pitting edema. The swelling was not associated with pain and tenderness. Palpable thick veins, distended veins or discoloration or cyanosis were not found in left lower limb. Patient was non smoker, non alcoholic and not having allergy to any drug or food item.

\section{Diagnosis, Assessment \& Treatment}

History and clinical examination are not reliable ways of diagnosing DVT. Lower extremity DVT may be symptomatic or asymptomatic [4]. Clinical diagnosis is difficult as the signs and symptoms are not specific in DVT. USG (Ultrasonography) of femoral and popliteal veins has both sensitivity and specificity of $97 \%$ in detecting DVT in symptomatic patients. ${ }^{[5]}$ Venous USG is the investigation of choice in patients stratified as DVT likely. It is non invasive, safe, easily available and relatively inexpensive. Diagnosis of DVT is made if venous USG is positive. ${ }^{[4]}$ In present case the diagnosis of DVT, ischemic stroke, hypothyroidism has been made based on the combination of positive venous USG findings, physical examination findings, imaging and thyroid profile (Table 1).

\begin{tabular}{|c|c|c|}
\hline Date & Name of Investigation & Report \\
\hline 26.08.2016 & CT scan of Head (Plain) & $\begin{array}{l}\text { No evidence of intra cranial hematoma; } \\
\text { Changes of cerebral atrophy; } \\
\text { Thickened frontal \& occipital skull valut; }\end{array}$ \\
\hline 01.09 .2016 & Lipid profile & Normal report \\
\hline \multirow[t]{3}{*}{16.09 .2016} & Echocardiography & Normal report \\
\hline & Hemoglobin & $11.1 \mathrm{gm} / \mathrm{dl}$ \\
\hline & $\begin{array}{l}\text { Peripheral smear for 'Malarial } \\
\text { parasite' }\end{array}$ & Negative \\
\hline 19.09 .2016 & X-Ray of chest (AP view) & $\begin{array}{l}\text { Ill defined radio opacity with 'Air bronchogram sign' seen in mid zone of } \\
\text { left lung; Consolidation; }\end{array}$ \\
\hline \multirow[b]{2}{*}{25.09 .2016} & Prothrombin time (PT) & 34.2 seconds \\
\hline & $\begin{array}{l}\text { Activated Partial Thromboplastin } \\
\text { Time (APTT) }\end{array}$ & 49.8 seconds (control - 30 seconds) \\
\hline 27.09 .2016 & Lower limb venous Doppler & DVT (Deep vein thrombosis) involving CFV, SFV \& Popliteal vein. \\
\hline 30.09 .2016 & Urine culture and sensitivity test & No pathogen was isolated after 48 hours of aerobic incubation; \\
\hline \multirow{5}{*}{05.10 .2016} & Hemoglobin & $10.2 \mathrm{gm} / \mathrm{dl}$ \\
\hline & RBC (Red blood corpuscles) count & 3.94 millions / micro litre \\
\hline & Hematocrit & $31.3 \%$ \\
\hline & Serum potassium & $3.3 \mathrm{~m} \mathrm{Eq} /$ litre \\
\hline & Urine analysis & Normal report \\
\hline 07.10 .2016 & PT & 36.2 seconds \\
\hline
\end{tabular}




\begin{tabular}{|c|c|c|}
\hline \multirow{9}{*}{20.10 .2016} & Thyroid stimulating hormone (TSH) & $46.66 \mathrm{u} \mathrm{IU} / \mathrm{ml}$ \\
\hline & Lower limb venous Doppler & DVT involving CFV, SFV \& PV. \\
\hline & Hemoglobin & $10.9 \mathrm{gm} / \mathrm{dl}$ \\
\hline & PT & 14.2 seconds \\
\hline & APTT & 25.4 seconds (control - 30 seconds) \\
\hline & Serum cholesterol & $218 \mathrm{mg} / \mathrm{dl}$ \\
\hline & Serum LDL & $140.3 \mathrm{mg} / \mathrm{dl}$ \\
\hline & Serum VLDL & $37.4 \mathrm{mg} / \mathrm{dl}$ \\
\hline & Cholesterol / HDL ration & 5.4094 \\
\hline \multirow{10}{*}{08.11 .2016} & Lower limb venous Doppler & $\begin{array}{l}\text { CFV shows minimal flow and non compressible indicating near complete / } \\
\text { partial thrombosis; SFV shows complete thrombosis; } \\
\text { ATV, PTV and PV are normal; }\end{array}$ \\
\hline & Hemoglobin & $11.6 \mathrm{gm} / \mathrm{dl}$ \\
\hline & PT & 13.1 seconds \\
\hline & APTT & 23.5 seconds (control - 30 seconds) \\
\hline & Bleeding time & 2 minute 15 seconds \\
\hline & Clotting time & 4 minute 38 seconds \\
\hline & Serum cholesterol & $258 \mathrm{mg} / \mathrm{dl}$ \\
\hline & Serum LDL & $173.3 \mathrm{mg} / \mathrm{dl}$ \\
\hline & Serum VLDL & $33 \mathrm{mg} / \mathrm{dl}$ \\
\hline & Cholesterol/HDL ration & 4.9903 \\
\hline 07.12 .2016 & Lower limb venous Doppler & $\begin{array}{l}\text { Partial reconciliation of proximal SFV and CFV; Complete thrombosis of } \\
\qquad S F V ;\end{array}$ \\
\hline
\end{tabular}

A criterion of assessment in present case was based on the findings of venous USG, lipid profile, thyroid profile, clinical improvement and other investigation reports. Total two assessments were taken, pre treatment (baseline) and post treatment (after 2 months completion of treatment). The patients was diagnosed as having 'Ekanga shotha [7] / Raktavrita vata [8] and pakshaghata' [9] according to Ayurveda and treated with various panchakarma procedures like Upanaha sweda (applying medicated paste over affected area) (Figure 2), Kashaya dhara (pouring decoction over affected area) (Figure 3), Udwartana (powder massage), Patra pottali pinda sweda (medicated bolus massage), Vasti (oil enema's and decoction enema's) and various internal medicines along with physiotherapy (Table 2). The purpose of treatment is to withdraw the patient from western medicines and to reduce the swelling initially; later the treatment was focused on to prevent the extension of thrombus, to prevent pulmonary embolism, to manage hypothyroidism, stroke, hypercholesterolemia and hypertension (Table 2).

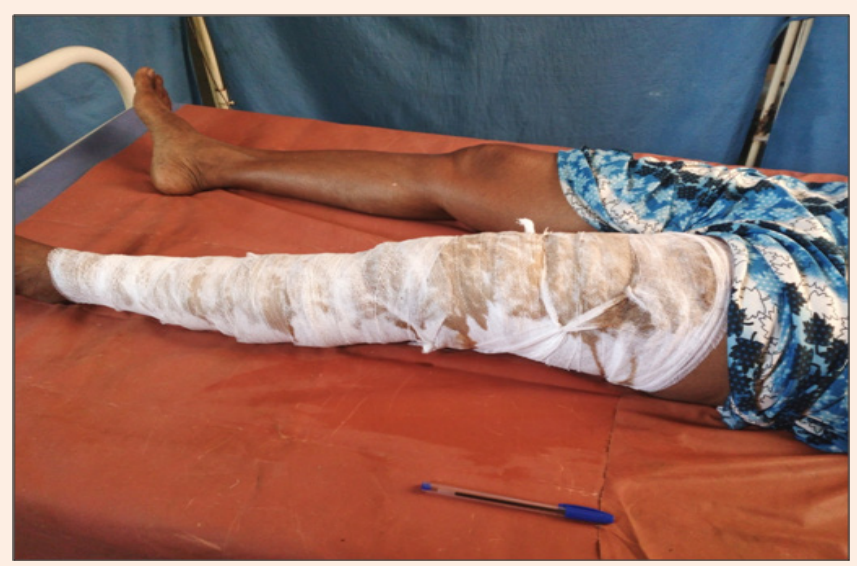

Figure 2: Upanaha sweda.

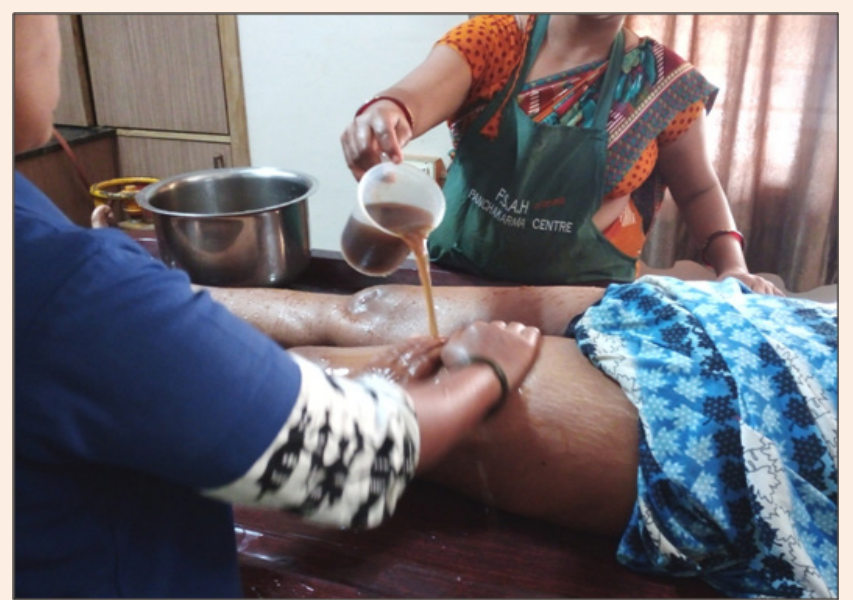

Figure 3: Kashaya dhara.

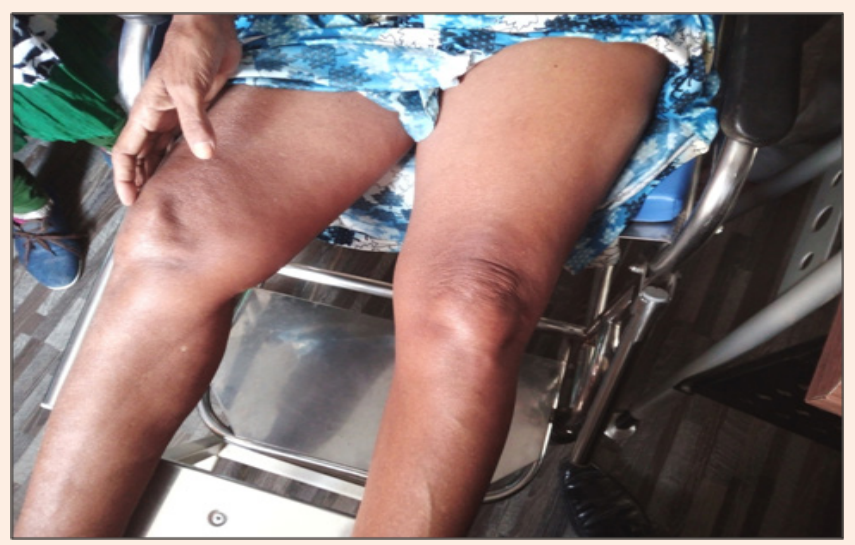

Figure 4: DVT - Left lower limb (after 1 month of treatment).

Citation: Mamidi P, Gupta K (2017) Ayurvedic Management of Deep Vein Thrombosis with Stroke and Hypothyroidism - A Case Report. Int J Complement Alt Med 9(2): 00288. DOI: 10.15406/ijcam.2017.09.00288 
Table 2: Intervention.

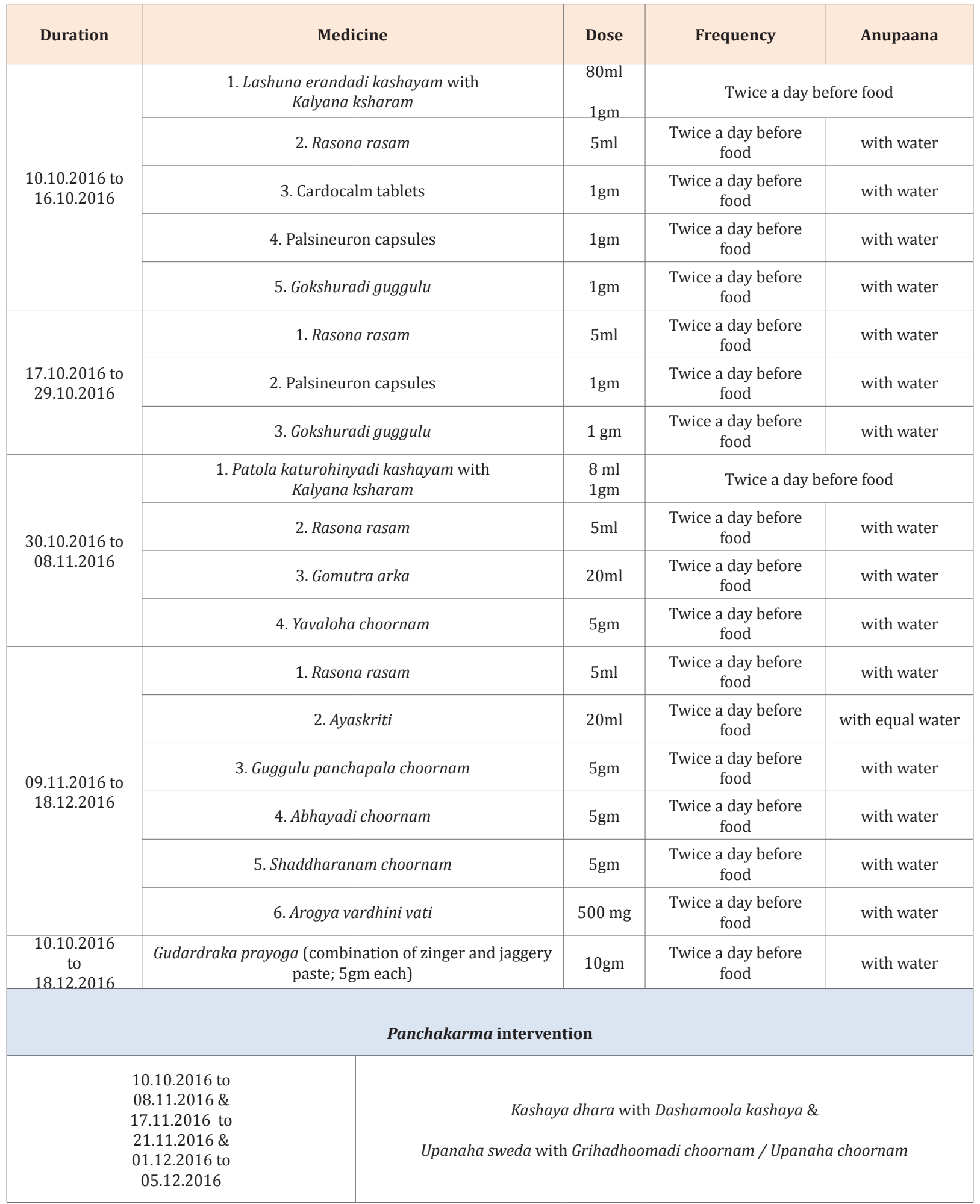




\begin{tabular}{|c|c|}
\hline $\begin{array}{c}09.11 .2016 \text { to } \\
16.11 .2016 \\
\text { (Yoga vasti schedule) }\end{array}$ & $\begin{array}{l}\text { 1. Patra pottali pinda sweda with Prabhanjana vimardana kuzambu } \\
\text { 2. Bashpa sweda (in steam chamber) } \\
\begin{array}{cc}\text { 3. Niruha vasti } \\
\text { (A. Saindhava lavana } & -6 \mathrm{gm} \\
\text { B. Madhu } & -150 \mathrm{ml} \\
\text { C. Nimbamrutadi eranda tailam } & -100 \mathrm{ml} \\
\text { D. Satapushpa kalkam } & -25 \mathrm{gm} \\
\text { E. Varanadi kwatha } & -500 \mathrm{ml} \\
\text { F. Gomutra arka } & -100 \mathrm{ml} \\
\text { G. Kalyanaka ksharam } \quad-3 \mathrm{gm} \text { (or) } \\
\text { 4. Anuvasana vasti with Shatahvadi anuvasana tailam }-80 \mathrm{ml}\end{array}\end{array}$ \\
\hline $\begin{array}{c}22.11 .2016 \text { to } \\
30.11 .2016 \& \\
07.12 .2016 \text { to } \\
12.12 .2016\end{array}$ & $\begin{array}{l}\text { 1. Patra pottali pinda sweda with Kottamchukkadi kuzhambu } \\
\text { 2. Anuvasana vasti with Pippalyadi anuvasana tailam }-80 \mathrm{ml}\end{array}$ \\
\hline $\begin{array}{l}13.12 .2016 \text { to } \\
18.12 .2016\end{array}$ & Udwartana with Kola kuluthadi choornam \\
\hline
\end{tabular}

\section{Discussion}

Thrombotic disorders are among the major fatal conditions affecting the society. ${ }^{[10]}$ DVT is a major and common preventable cause of death worldwide. It affects approximately $0.1 \%$ of persons per year. The term thrombosis refers to the formation of an abnormal mass within the vascular system of a living animal. When this process occurs within the deep veins, it is referred to as DVT. The goal of therapy for DVT is intended to prevent the extension of thrombus, acute pulmonary embolism, to prevent recurrence of thrombosis and to prevent the development of late complications such as pulmonary hypertension and post thrombotic syndromes [4]. Several plants such as Ocimum sanctum, Curcuma longa, Azadirachta indica, Anacardium occidentale, Molineria recurpata, Terminalia belirica, Tulbaghia violaceae, Melastoma malabathricum, Gloriosa superb, Jatropha curcas, porana volubilis, Synclisia scabrida, Allium sativum and Allium cepa have been proved to possess thrombolytic activity [10]. Tinospora cordifolia and Saussurea lappa showed mild thrombolytic activity [6].

The patient has been taking various drugs like anti hypertensives, aspirin, warfarins, thyroid supplements, fibrinolytic drugs, multi vitamins and laxatives. All these medicines were gradually tapered, completely withdrawn and replaced with Ayurvedic medicines during the initial stages of treatment. Various drugs like, lashuna erandadi kashaya and rasona rasam (which contains Allium sativum as main ingredient), guggulu preparations (Commiphora mukul), kalyana ksharam (alkali preparation) and arogya vardhini vati were prescribed to reduce the thrombosis and to manage hypercholesterolemia. Ayaskriti was used to improve hemoglobin levels. Cardocalm tablets were used to manage hypertension (Table 2).

Kashaya dhara with 'Dashamoola kashaya' and Upanaha sweda with 'Grihadhoomadichoorna'/'Upanahachoorna'were prescribed to reduce the swelling of left lower limb. After 9 days of these procedures the swelling of left thigh (mid thigh circumference) got reduced from 21 to 18 inches, left knee swelling from 14.5 to 14 inches and left calf (mid calf circumference) swelling from 12 to 10.8 inches (Figure 4). Yoga vasti schedule (alternate oil enema and decoction enema protocol for 8 days) and Patra pottali pinda sweda were implemented to treat the left side hemi paresis after complete disappearance of left lower limb swelling. Rookshana (dry / rough) procedure like Udwartanam (massage with herbal powders) with 'Kola kuluthadi choornam' was prescribed after vasti schedule. Gudardraka prayoga (internal administration of equal amounts of jaggery and ginger daily) has been advised to cure and prevent the further extension of thrombosis of deep veins and also to prevent pulmonary embolism.

Patient's sleep, appetite and quality of life were improved. Left lower limb swelling was completely reduced (Figures 1 \& 4). The patient has been taking western medicines for her multiple problems; all of them were successfully tapered, stopped and replaced with Ayurvedic medicines. Good improvement is noticed in hemoglobin levels, lipid profile, clotting factors like prothrombin time (PT) and activated partial thromboplastin time (APTT) with Ayurvedic treatment. From complete thrombosis of SFV, CFV and popliteal vein to partial reconciliation of proximal SFV and CFV is noticed in lower limb venous Doppler after two months completion of an Ayurvedic treatment (Table 1). Spasticity of left upper limb got reduced and patient felt better with Ayurvedic treatment. No adverse effects were reported by the patient. The patient got clinically meaningful improvement by internal medicines along with dietary restrictions (advised to avoid dairy products, salt and advised to drink hot water) and physiotherapy. Ayurvedic treatment seems to be promising in the management of DVT with stroke and hypothyroidis with in short period of time and without causing any adverse effects. 


\section{Conclusion}

The Ayurvedic diagnosis of 'Ekanga shotha /Raktavrita vata' is made for 'DVT' in present case. Various Ayurvedic panchakarma procedures and internal medicines have provided promising results especially in reducing the swelling, decreasing the severity of thrombosis in deep veins, managing various associated conditions like hypothyroidism, hypercholesterolemia, hypertension, stroke in a better way and also improving quality of life without causing any adverse effects in present case. Present study findings can't be generalized and further long term follow up studies with large sample are required to substantiate these claims.

\section{Acknowledgment}

None.

\section{Conflict of Interest}

None.

\section{References}

1. Kaur R, Chhabra S, Singh A (2015) Role of Ayurvedic medicine and leech therapy in management of deep vein thrombosis: A case study. J Biol Sci Opin 3(2): 87-90.

2. Scarvelis D, Wells PS (2006) Diagnosis and treatment of deep-vein thrombosis. CMAJ 175(9): 1087-1092.

3. Saxena V, Shukla D, Bharadwaj PK (2012) Evaluation of effect of Jalukavacharana on deep vein thrombosis. The Indian Journal of Research 6: 42-45.
4. Kesieme E, Kesieme C, Jebbin N, Irekpita E, Dongo A (2011) Deep vein thrombosis: A clinical review. J Blood Med 2: 59-69.

5. Narani KK (2010) Deep vein thrombosis and pulmonary embolismprevention, management and anaesthetic consideration. Indian J Anaesth 54(1): 8-17.

6. Chaudhary S, Godatwar PK, Sharma R (2015) In vitro thrombolytic activity of Dhamasa (Fagonia arabica Linn), Kushta (Saussurea lappa Decne.) and Guduchi (Tinospora cordifolia Thunb.). AYU 36(4): 421424

7. Vriddha Vagbhata (2012) Ashtanga Sangraha commentary by Indu, Nidaana sthaana, Paandu roga kamala shopha visarpa nidaanam adhyaya, 13/18. In: Dr. Shivprasad sharma (Ed.), (3 $3^{\text {rd }}$ edn), Chowkhamba Sanskrit series office, Varanasi, India, pp. 404-405.

8. Vriddha Vagbhata (2012) Ashtanga Sangraha commentary by Indu, Nidaana sthaana, Vaata vyaadhi nidaanam adhyaya, 15/26. Shivprasad sharma. Varanasi: Chowkhamba Sanskrit series office, Varanasi, India, pp. 415.

9. Vriddha Vagbhata (2012) Ashtanga Sangraha, commentary by Indu, Nidaana sthaana, Vaata shonita nidaanam adhyaya, 16/27. In: Shivprasad sharma (Ed.), (3 $3^{\text {rd }}$ edn), Chowkhamba Sanskrit series office, Varanasi, India, pp. 419.

10. Fathima SN, Ahmad SV, Kumar BR (2015) Evaluation of In Vitro Thrombolytic Activity of Ethanolic Extract of CURCUMA CAESIA Rhizomes. International Journal of Pharma Research \& Review 4(11): 50-54. 